\title{
Laikusok onkológiai ellátáshoz kapcsolódó ismeretei, tapasztalatai és attitúdjei
}

\author{
Feith Helga Judit dr. ${ }^{1}$ - Szőke Andrea ${ }^{1}$ - Ábrám Boróka ${ }^{1}$. Tóth Erika dr. ${ }^{2}$ \\ ${ }^{1}$ Semmelweis Egyetem, Egészségtudományi Kar, Társadalomtudományi Tanszék, Budapest \\ ${ }^{2}$ Országos Onkológiai Intézet, Sebészeti és Molekuláris Patológiai Osztály, Budapest
}

\begin{abstract}
Bevezetés: A kutatásokban jóval kisebb hangsúlyt kap a betegek és hozzátartozók betegjogi és ellátásszervezési ismereteinek és együttmúködésükkel kapcsolatos attitúdjeinek a felmérése. Célkitüzés: Hiánypótló kutatásukban a szerzők legfontosabb célkitúzése az volt, hogy felmérjék az onkológiai ellátásban megjelenő laikusok ellátásszervezési ismereteit, valamint attitűdjeit. Módszer: Az adatok felvételét két nagy betegforgalmú helyszínen végezték, szóbeli interjú formájában (n = 271). Eredmények: A válaszadók 26,1\%-a egyáltalán nem szerez be további információt feltételezett/ bizonyított betegségéről. $69,0 \%$ vélte úgy, hogy a patológus kizárólag halottakkal foglalkozik vagy pedig egyáltalán nem tudta, mi a feladata. Mindössze a válaszadók 39,7\%-a jelezte, hogy a daganatos betegség típusának meghatározásában a patológus szerepet játszik. Ez utóbbi két eredményt nem befolyásolta a válaszadók iskolai végzettsége. Következtetések: Bizonyítható, hogy sokan nem ismerik, s bár iskolai végzettség függvényében változott a válasz, de magas százalékban nem is akarják megismerni az onkológiai ellátás múködését. A szerző́k véleménye szerint a laikusok informáltsága magasabb szintú betegellátáshoz, s ezzel összefüggésben nagyobb betegbiztonsághoz vezetne. Orv. Hetil., 2016, 157(33), 1314-1319.
\end{abstract}

Kulcsszavak: onkológiai ellátás, betegbiztonság, ellátásszervezési ismeretek, patológusmunka

\section{Knowledge, experience and attitudes of laymen in oncological health services}

Introduction: There is much less emphasis on the survey of the laymen's attitudes towards their awareness of patients' rights and organization of care, and cooperation. Aim: The most important goal of this niche study was to explore how much laymen know about the organization of care and to assess their attitudes when they are under oncological care. Method: Data collection was completed in outpatient oncology departments in two different hospitals treating high number of patients $(\mathrm{n}=271)$. Results: $26.1 \%$ of the respondents did not collect further information about their supposed disease. $69.0 \%$ thought that the pathologist deals exclusively with the dead or did not know what their duties are. Only $39.7 \%$ of the respondents indicated that the pathologist plays a role in the diagnostic process of cancers. The latter two findings were not influenced by the respondents' level of education. Conclusions: There is a clear evidence that the majority of the respondents were not familiar with the organisationof the care in oncology and, depending on the level of their education, a high percentage does not even want to learn about it at all. The authors propose that informing the layman would lead to a higher quality of patient care, and consequently to greater patient safety.

Keywords: oncology care, patient safety, organization of care knowledge, pathologist work

Feith, H., J., Sző́ke, A., Ábrám, B., Tóth, E. [Knowledge, experience and attitudes of laymen in oncological health services]. Orv. Hetil., 2016, 157(33), 1314-1319.

(Beérkezett: 2016. május 11.; elfogadva: 2016. június 9.)

\section{Rövidítések}

BEGYKA = Betegjogi, Ellátottjogi és Gyermekjogi Közalapítvány; Eü. tv. = Az egészségügyről szóló 1997. évi CLIV. tör- vény; OBDK = Országos Betegjogi, Ellátottjogi, Gyermekjogi és Dokumentációs Központ; WHO = World Health Organization 
Az egészségügyről szóló 1997. évi CLIV. törvény (továbbiakban Eü. tv.) hatályba lépését követően az egészségügyi szolgáltatókkal szemben egyre több kártérítési eljárás indult és számottevően nőtt a betegpanaszok szá$\mathrm{ma}$ is. Egy 2013-ban napvilágot látott adat szerint a magyar egészségügyi szolgáltatókkal szemben évról évre megközelítőleg 400-500 kártérítési per kezdődik, s a bíróság által megítélt kárösszegek évente hozzávetőlegesen 2 milliárd forintot tesznek ki [1]. A betegjogi panaszok számáról egészen pontos adatok nem állnak rendelkezésünkre, hiszen nagyon nehéz objektíven nyomon követni a jogsértések számát. Az egyik legismertebb adatsort a 2011-ben megszüntetett Betegjogi, Ellátottjogi és Gyermekjogi Közalapítvány (BEGYKA) jelentette meg az országosan múködő, akkor még 52 betegjogi képviselő megkereséseiről. Ez alapján 2004 és 2008 között meredek emelkedést mutatott a betegjogi képviselők iránti megkeresések száma (2004-ben 6750, míg 2008-ban már 16600 megkeresést regisztráltak), ezt követôen némi visszaesést lehetett tapasztalni, de maradt a tízezres nagyságrend [2]. A 2012-ben létrejött Országos Betegjogi, Ellátottjogi, Gyermekjogi és Dokumentációs Központ (OBDK) jelentése szerint 2015-ben 14080 megkeresés érkezett, az összes megkeresés 36\%-a volt panasz [3].

A korábban megjelent adatok - nem meglepó módon - azt is jelezték, hogy a betegjogi jogsértések nagyobb hányada ott jelentkezik, ahol magas az igényoldali túlterhelés. Ez a túlterheltség az onkológiai ellátás területét is érinti, miközben köztudott, hogy a hazai mortalitási és morbiditási adatok nagy hányada az onkológiai ellátás területén jelentkezik.

$\mathrm{Az}$ Eurostat 2015 áprilisában megjelent adatai szerint (2012) Magyarországon a rosszindulatú daganatos megbetegedések okozta halálozások száma 361,1/100 ezer fó, míg az EU átlaga 266,9/100 ezer fó [4]. Hazánkban a standardizált halálozási mutatók alapján minden 4 . ember $(28,0 \%)$ daganatos betegség miatt hal meg [5]. Életkor tekintetében is elgondolkodtató képet mutatnak a mérőszámok. A fiatal nők halálozásában 44\%-ot tesznek ki a daganatos betegségek, míg a férfiak esetében 34\%ot. Az összes halálozáson belül ez az arány nőknél 23\%, férfiaknál 29\% [6]. Ugyancsak figyelemfelhívó az is, hogy $28,3 \%$ esélye van egy magyar embernek arra, hogy 75 éves koráig daganatos megbetegedés jelentkezzen [7]. Ezekből az adatokból láthatjuk, hogy nagymértékú a probléma és igencsak aktuális jelenünket és jövőnket tekintve.

Hiánypótló kutatásunk fó célkitűzése az volt, hogy betegbiztonsági megközelítésből ismerjük meg az onkológiai járóbeteg-ellátásban megjelenő betegek és hozzátartozók/kísérők (továbbiakban kísérők) betegséggel, onkológiai ellátásszervezéssel (különös tekintettel a patológus feladatkörére) és betegjogok gyakorlásával öszszefüggő tapasztalataikat, attitüdjeiket.

\section{Módszer}

Nagy betegforgalommal bíró, eltérő földrajzi régiójú (egy fővárosi és egy nem fővárosi) egészségügyi intézményben, személyes interjúvétel alapján, az onkológiai járóbeteg-szakellátásban megforduló betegek és kísérőik körében készült a pilot felmérés. A 2015. augusztusszeptember közötti adatgyújtést megelózően megtörtént az intézményi kutatási engedélyek beszerzése. A felmérés a vonatkozó kutatásetikai szabályoknak megfelelően zajlott; az interjúalanyok önkéntesen és név nélkül vállalkoztak a kérdések megválaszolására.

A standardizáltság, az adatok összehasonlíthatósága, valamint a téma kutatásának pilot jellege miatt kutatási módszerként a strukturált interjúkészítés került kiválasztásra. A 66 változóból álló kérdőív leginkább zárt kérdéseket tartalmazott, de a 6 nyitott kérdés, illetve a személyes interjúforma lehetővé tette a formalizált interjútól való eltávolodást. A legtöbb interjú $20-30$ perces volt, a megszólított válaszadók többsége nem utasította el a kutatásban való részvételt. Ugyanakkor a női válaszadók valamivel nyitottabbak voltak arra, hogy részt vegyenek a kutatásban. Összesen 271 interjú készültt, ebből a budapesti interjúk száma 121 (44,6\%), míg a nem fơvárosiaké $150(55,4 \%)$ volt. Az interjúalanyok 66,4\%-a betegként érkezett az intézménybe, míg 33,6\%-uk kísérooként. Az interjúalany betegek leginkább kezelésre $(41,9 \%)$, valamint kontrollra érkeztek $(32,4 \%)$.

Az összehasonlítható adatok feldolgozása az SPSS 22 program segítségével történt. A megoszlási vizsgálatok mellett Pearson-féle $\chi^{2}$-próba történt $(\mathrm{p}<0,05)$.

\section{Eredmények}

\section{Szociodemográfiai jellemzök}

A válaszadók 39,5\%-a férfi, míg 60,5\%-a nő volt, átlagéletkoruk 55,9 év volt. Legtöbben $(36,2 \%)$ közép- és kisvárosban éltek, ezt követte a falun/tanyán élók száma $(26,2 \%)$, a válaszadók közel egyötöde a fóvárosban élt $(22,5 \%)$, a megyeszékhelyen élók aránya pedig $15,1 \%$ volt. A válaszadók több mint egyharmada érettségivel rendelkezett $(34,3 \%)$; szakiskolát/szakmunkásképzőt végzett $29,2 \%$-uk. A nyolc általánost vagy annál kevesebbet végző́k aránya volt a legalacsonyabb $(12,9 \%)$; a felsőfokú végzettségúek aránya $23,6 \%$ volt. Az iskolai végzettség nem mutatott összefüggést az életkorral $(\mathrm{p}=$ 0,290 ), ugyanakkor az állandó lakóhely típusával szignifikáns korreláció volt megfigyelhető $(\mathrm{p}<0,001)$. A magasabb iskolai végzettségúek a nagyobb lélekszámú településeken éltek; a diplomások 50,0\%-a megyeszékhelyt vagy a fóvárost jelölte meg állandó lakóhelyként. A fơvárosi intézmény válaszadói magasabb iskolai végzettséggel rendelkeztek $(\mathrm{p}=0,001)$.

A kísérók 31,5\%-a jelezte, hogy az onkológiai ellátásban ők maguk betegként is megjelentek már korábban, 
vagyis az összes interjúalany háromnegyede (75,2\%-a) közvetlen betegtapasztalatokkal bírt a hazai onkológiai ellátásról.

\section{Ismeretszerzés a betegséggel összefüggésben}

$\mathrm{Az}$ interjúalanyok közel egyharmada $(32,8 \%)$ betegség gyanúja esetén már a pontos diagnózis előtt próbál állapotával kapcsolatos információkat beszerezni, ugyanakkor 26,1\%, vagyis minden negyedik személy sem a diagnózis előtt, sem a diagnózis után nem szerez be egyéb információkat (1. ábra).

Az iskolai végzettség nagyon erős statisztikai összefüggést mutatott ezzel a válasszal $(\mathrm{p}<0,001)$. Megállapíthatjuk, hogy minél magasabb volt a kérdezett iskolai végzettsége, annál inkább tájékozódott már a diagnózis megszületése előtt állapotáról, lehetséges betegségéről: a 8 általánost vagy kevesebb osztályt végzettek 14,3\%-a, míg a diplomások 53,1\%-a teszi ezt. Minél magasabb volt a kérdezettek iskolai végzettsége, annál kisebb arányban fordul elő az, hogy még a diagnózis után sem tájékozódik: a 8 általánost vagy kevesebb osztályt végzettek 60,0\%-a, míg a diplomások 9,4\%-a tartozott ez utóbbi kategóriába. Gyengébb statisztikai összefüggést $(\mathrm{p}=0,050)$ találtunk arra vonatkozóan, hogy betegként vagy kísérőként válaszolt a személy erre a kérdésre. A kísérők 40,4\%-a, míg a betegek csak 28,7\%-a tájékozódik betegség gyanúja esetén a diagnózis előtt; s magasabb volt a betegek körében azoknak az aránya is (betegeknél 30,5\%, kíséróknél csak 18,0\%), akik semmikor nem tájékozódnak, még felállított diagnózis esetén sem. A válaszadók neme, az intézmény földrajzi elhelyezkedése, az

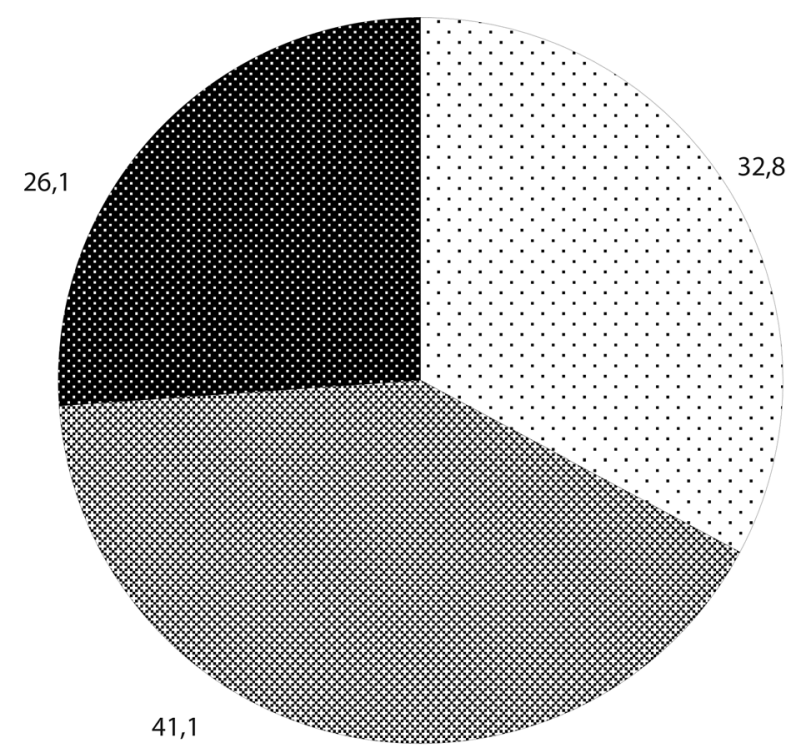

$\because$ Diagnózis előtt Diagnózis után $\quad$ Nem néz utána

1. ábra Információszerzés a betegség gyanúja/pontos diagnózisa esetén (\%) $(\mathrm{N}=271)$ életkor, a korábbi onkológiai osztállyal kapcsolatos tapasztalatok nem befolyásolták a kérdésre adott választ. Ugyanakkor megállapítható, hogy a kísérôk valamivel magasabb iskolai végzettséggel bírtak (bár statisztikailag nem megalapozható a különbség; $\mathrm{p}=0,086)$. Míg a kísérók $51,7 \%$-a legalább érettségizett volt, addig a betegek esetében ez az arány csak $35,8 \%$ volt.

Bármilyen korábbi egészségügyi ellátás során a válaszadók igen kis hányada tekintett be a teljes betegdokumentációba $(12,7 \%)$, kérte azt ki $(9,0 \%)$ vagy másoltatta le $(1,2 \%)$. Sokan nem is tudták, hogy ezekre van lehetőség: a dokumentáció lemásolásáról 34,7\%, annak kiadásáról 20,8\%, s az abba való betekintés lehetőségéról $18,4 \%$ nem tudott.

Csupán minden tizedik válaszadó jelezte (10,0\%), hogy gyakran vagy szinte mindig kikéri egy második szakorvos véleményét a diagnózisáról/kezeléséről. Erre a kérdésre 62,1\% azonban a „soha” választ adta. Ezt nem befolyásolta a válaszadó neme, az életkora, az intézmény, a korábbi onkológiai osztállyal kapcsolatos tapasztalatai, de az sem, hogy beteg vagy kísérő volt-e. Ugyanakkor a kérdezettek iskolai végzettsége az erre a kérdésre adott válaszokat erősen befolyásolta, erre statisztikailag erős bizonyítékot kaptunk ( $\mathrm{p}=0,004)$. Megközelítőleg minden ötödik diplomás válaszadó $(20,3 \%)$ gyakran vagy szinte mindig kikéri másik szakorvos véleményét, míg ez az arány a 8 általánost vagy annál kevesebb osztályt végzettek esetében csak 8,6\%. A diplomások 43,8\%-a, a legalacsonyabb iskolai végzettségúek $71,4 \%$-a adott erre a kérdésre „nem, soha” választ.

Az interjúalanyok közül nagyon kevesen (14 fö, vagyis mindössze a minta 5,2\%-a) kérték ki szövetmintájukat azért, hogy más egészségügyi intézménybe elvigyék második szakvéleményre. Közülük 6 fö volt budapesti, 8 fó pedig nem fóvárosi. Nemi megoszlás tekintetében 11 nő és 3 férfi adott ilyen választ. Majdnem a felük (6 fó) a 40-49 éves korosztályba tartozott és diplomás volt. (A 8 általánost vagy ennél kevesebbet végzett személyek közül egy sem volt, aki kikérte volna a szövetmintáját.) Ebben a kérdéskörben egyébként nagy volt a bizonytalanság, hiszen a betegek/kísérók 46,5\%-a nem is tudta, hogy egyáltalán van-e joga ehhez. Közel egynegyedük (23,8\%) szerint ez egyáltalán nem lehetséges, 29,7\%-uk szerint viszont ki lehet kérni a szövetmintát. Az erre a kérdésre adott válaszokat nem befolyásolta a válaszadó neme, az életkora, az intézmény (fóvárosi vagy nem fövárosi), a korábbi onkológiai osztállyal kapcsolatos tapasztalatai, valamint az sem, hogy kíséróként/betegként válaszolt a kérdéseinkre.

\section{Ismeretszerzés, tapasztalatok az onkológiai ellátással összefüggésben}

A válaszadók megközelítőleg kétharmada $(65,4 \%)$ nyitott arra, hogy megismerje kezelésének folyamatát, mintegy egynegyedüket $(26,7 \%)$ azonban ez nem érdekli. A két intézmény résztvevőinek válaszai kifejezett eltérést 
mutattak ennél a kérdésnél, erős statisztikai bizonyítékot kaptunk erre vonatkozóan $(\mathrm{p}<0,001)$. A budapesti intézményben többen $(74,4 \%)$, míg a nem fóvárosi intézményben kevesebben $(58,4 \%)$ szeretnék ismerni a kezelésük folyamatát. Az iskolai végzettség tekintetében ugyancsak erôs statisztikai bizonyítékot kaptunk a különbségre $(\mathrm{p}=0,001)$. A diplomások $77,8 \%$-a, a gimnáziumot végzettek $82,6 \%$-a, a szakközépiskolát végzettek 62,8\%-a, a szakiskolát/szakmunkásképzőt végzettek 54,4\%-a, míg az ennél alacsonyabb iskolázottságú személyek 48,6\%-a szeretné ismerni kezelésének folyamatát. Elutasító volt a legalacsonyabb iskolai végzettségúek 45,7\%-a, míg ez az arány a diplomások esetében csak $17,5 \%$ volt. A válaszadó neme, kísérő/beteg mivolta nem befolyásolták a kérdésekre adott válaszokat.

Nyitott kérdésünkre, miszerint „Kezelésének folyamatában mire lenne nagyon kíváncsi?”, a többség $(51,4 \%)$ nem igazán adott választ, leginkább azért, mert nem tudott olyat megnevezni, amire nagyon kíváncsi lett volna. Azok közül, akik pontos választ adtak, legtöbben az eredménnyel kapcsolatos folyamatot szeretnék ismerni, ezt a válaszadók 18,5\%-a jelölte meg. 14,0\% konkrétan a kezelésre lenne kíváncsi; $9,5 \%$ a kezelés mellékhatásaira és gyógyító hatásaira; $5,0 \%$ a további lehetôségekre; míg $1,8 \%$ az előzményekre, a betegség kialakulására vonatkozóan szeretne nagyobb rálátást.

A válaszadók mindössze 11,6\%-a vett részt valaha oncoteam-megbeszélésen, vagyis a kutatásunkban részt vevők túlnyomó hányadának nincs ilyen irányú közvetlen tapasztalata. Az oncoteam-megbeszélésen részt vevők $87,1 \%$-a a budapesti intézmény válaszadói közül került ki. Az onkológust szinte minden válaszadó az oncoteam tagjának tekintette $(96,5 \%)$, a radiológust 78,8\%-uk, míg a patológust ennél sokkal kisebb arányban, $56,2 \%$-uk jelezte.

\section{Ismeretek a patológus onkológiai ellátásban megjelenö szerepével összefüggésben}

A kutatásban részt vevő személyek 84,5\%-a még sohasem beszélt betegként vagy kíséróként patológussal. A válaszadók többsége nem is volt tisztában azzal, hogy a patológus milyen feladatokat lát el a mindennapi munkája során. Legmagasabb arányban egyértelmúen a boncolások végzésével foglalkozó szakemberként $(42,2 \%)$ vagy csak betegségek diagnózisával foglalkozó szakemberként $(25,3 \%)$ ismerik a patológust. Az interjúalanyok $16,8 \%$-a viszont egyáltalán nem tudta, hogy mi a szerepe az egészségügyi ellátásban. Vagyis eredményeink alapján megállapítható, hogy a többség $(84,3 \%)$ nem vagy nem jól ismeri a patológus szerepét az onkológiai ellátásban. Mindössze a válaszadók 15,7\%-a tudta helyesen, hogy betegségek diagnózisával, szövettani diagnosztikával és boncolással egyaránt foglalkozhat a patológus. Az életkor $(\mathrm{p}=0,005)$ befolyásolta a patológus feladatkörére adott válaszokat. A középkorúak inkább tudták helyesen a patológus feladatkörét, szemben a legfiatalabb és a leg-

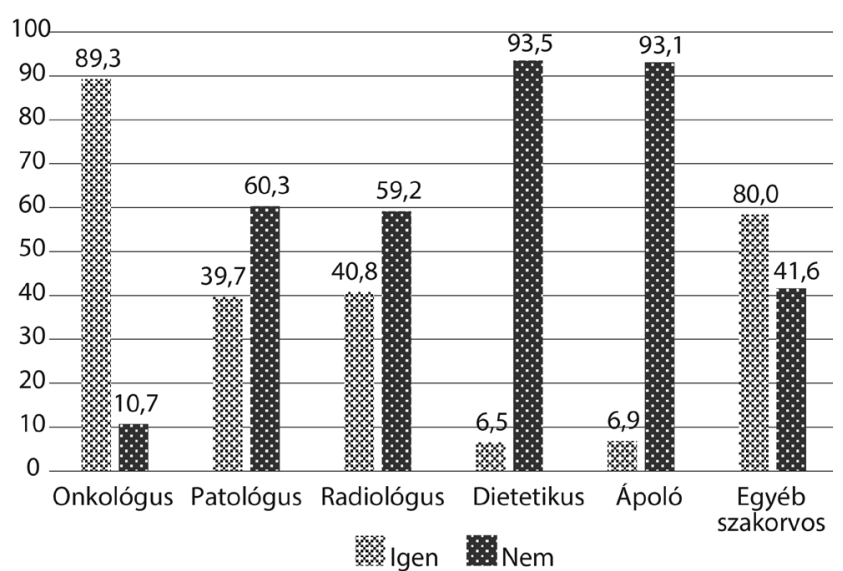

2. ábra

A daganatos betegségek diagnózisát felállító szakemberek a laikusok szerint $(\%)(\mathrm{N}=262)$

idősebb korcsoporttal. Meglepő módon sem az iskolai végzettség, de az intézmény, a korábbi onkológiai tapasztalatok sem befolyásolták az erre a kérdésre adott válaszokat, sőt az sem, hogy beteg vagy kísérő volt a válaszadó.

További kérdések is vizsgálták a patológusok onkológiai ellátásban megjelenő szerepét. A kutatásban részt vevốknek meg kellett határoznia egy zárt kérdés segítségével, hogy kik állítják fel a daganatos betegségek gyanúja esetén a pontos diagnózist. A 2. ábra markáns különbségeket mutat a válaszok között. Jól tetten érhető, hogy a válaszadók többsége $(60,3 \%)$ szerint a patológus nem vesz részt a diagnózis felállításában. Az erre a kérdésre adott válaszokat nem befolyásolta az interjúalany neme, iskolai végzettsége, de az sem, hogy betegként vagy kísérőként jelent meg az interjú idején az egészségügyi intézményben.

Egy másik - a patológusok onkológiai ellátásban megjelenő szerepére vonatkozó - kérdés is megerősítette a fentieket. A 3. ábrán jól látható, hogy az interjúalanyok a daganatos betegségek megállapításában az onkológus $(57,5 \%)$ és az egyéb szakorvos $(18,3 \%)$ mögött a patológust csak a 3 . helyen jelölték meg, mint legfontosabb szereplőt $(16,5 \%)$. Az erre a kérdésre adott válaszokat nem befolyásolta az interjúalany neme, az életkora, az iskolai végzettsége, de az sem, hogy kísérő vagy beteg volt, mint ahogyan a kérdezettek korábbi onkológiai osztállyal kapcsolatos tapasztalatai sem.

\section{Megbeszélés}

Kutatásunk egyik nagyon fontos tanulsága az volt, hogy a betegek és/vagy kíséroóik nagy hányada kevésbé él az egyébként jog által biztosított elónyökkel, vagyis a hatályos egészségügyi törvényben szabályozott betegjogokkal (például tájékoztatáshoz való jog, egészségügyi ellátáshoz való jog, az egészségügyi dokumentáció megismerésének joga). Így például a beteg kezdeményezhetné a kezelőorvos által megállapított diagnózis egy másik 


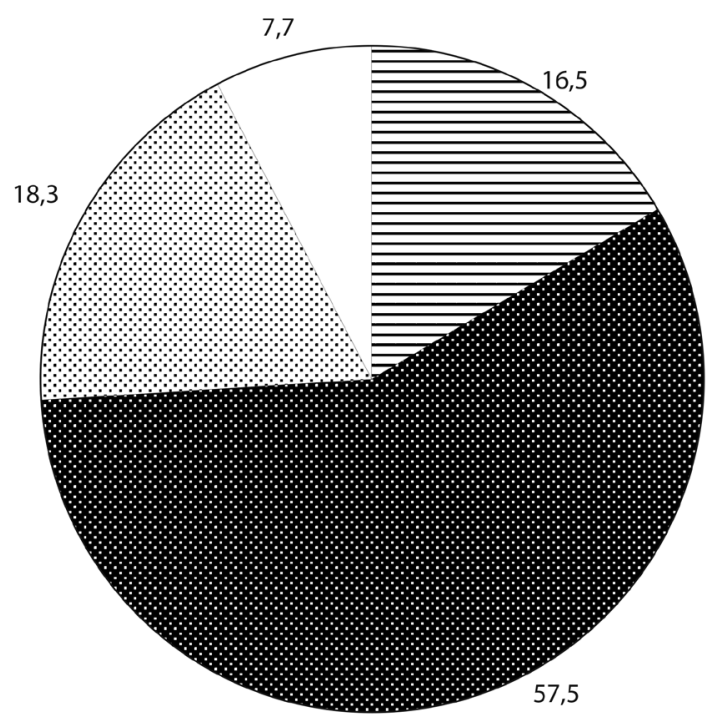

三 Patológus

3. ábra $\mid$ A daganatos betegség megállapításában legfontosabb szerepet betöltő megjelölt személyek (\%) $(\mathrm{N}=261)$

orvos által történő felülvizsgálatát [8], s ezt a jogot térítésmentesen egy alkalommal jogosult is lenne gyakorolni [9], azonban az interjúalanyok közül nagyon kevesen éltek ezzel a lehetősséggel. Ez adódhat az ismerethiányból, de akarathiányból is. Ebben a kutatásban jól tetten érhető egy olyan laikus réteg (leginkább a legalacsonyabb iskolai végzettségüek, illetve az idősebbek), akik a saját egészségi állapotuk tekintetében közömbösnek mutatkoztak, s ezáltal nem éltek a tájékoztatáshoz való jogukkal, az egészségügyi dokumentáció megismerésének jogával. Több interjúalany azt feltételezte, hogy a kiadott lelet egyenértékü a betegdokumentációval.

A kutatásunk eredményei szerint a magasabb iskolázottságúak, a nők, valamint a fiatalabb életkorúak sok tekintetben nyitottabbak az ismeretszerzésre, a betegjogaik gyakorlására.

Eredményeink szerint az interjúalanyok csak igen kis százaléka ismerte az oncoteam múködését is, miközben nyilvánvaló, hogy az igen összetett, s a laikusok számára sokszor áttekinthetetlen onkológiai ellátás alapkövetelménye a multidiszciplináris jellegű oncoteam széles körú múködése [10].

A diagnosztikai eszközök folyamatos fejlődése lehetővé teszi, hogy a daganatos betegséggel küzdők egyénre szabott terápiához juthassanak, a daganat típusától függően, az eltérő morfológiai és az ezzel együtt különböző genetikai tulajdonságokkal rendelkező tumorok kezelésében. Ez azt jelenti, hogy egyre pontosabb diagnózisokat képesek felállítani a patológusok, ami a terápia alapja és a kezelés sikerességének kulcsa [11]. Ezzel szemben a kutatásban részt vevő személyek (betegek és kísérőik) ismeretszintje sok tekintetben nem volt kielégítő. Annak ellenére, hogy az onkológiai ellátásban megnyilvánuló érintettségük nyilvánvaló volt, s a betegek nagyobb hányada $(59,4 \%$-a) havonta vagy annál gyakrabban jelent meg az onkológiai osztályon, kevesen ismerték például a patológus orvos onkológiai ellátásban játszott szerepét. S míg nagyon markáns különbségeket lehetett leírni számos más változó és az iskolázottsági szintek hatása között (például tájékozottsághoz kapcsolódó attitűdök), ebben a kérdéskörben a magasabb iskolai végzettség nem jelentett védőfaktort, hiszen a kvalifikáltabb interjúalanyok sem rendelkeztek kellő ismerettel a patológus orvosok napjainkban megnyilvánuló, igen fontos diagnosztikai, prognosztikai és prediktív szerepéról.

Megállapítható, hogy a patológusok egymás közötti napi szintú konzultációja elengedhetetlen betegbiztonsági kérdés, hiszen valid diagnózis alapján lehet a megfelelő beavatkozást elvégezni. Ugyanakkor a kórmeghatározásban kulcsfontosságú szerepet betöltő patológus szakorvosok száma Magyarországon jelentősen elmarad az igényektől, és az ebből fakadó leterheltségük miatt a diagnosztikai tévedések kockázata és a kórmeghatározás ideje is megnövekedett. Ezek együttesen a betegek gyógyulási esélyeinek csökkenéséhez vezethetnek.

Az egészségügyi szolgáltatókkal, illetve az egészségügyi dolgozókkal szemben kezdeményezett felelősségi eljárások, a betegjogi panaszok számának tendenciája a mindennapos egészségügyi ellátásban egyre inkább érezteti hatását, így megjelent és egyre inkább „terjed” a defenzív gyógyítás gyakorlata. Miközben ez nem segíti elő a betegek költséghatékonysági szempontokat figyelembe vevő, optimális gyógyulását.

A fenti ellátásszervezési nehézségek figyelembevételével meggyőződésünk, hogy a betegedukáció, a laikusok tudásszintjének emelkedése javíthatja az orvos-beteg kommunikáció hatékonyságát, ezzel együtt nőne a betegek együttmúködési hajlandósága, javulna gyógyulásuk esélye, emelkedne a betegbiztonság, elkerülhetővé válnának, de legalábbis csökkenthető lenne az orvosi múhibák bekövetkeztének valószínüsége.

Mindenképpen érdemes lenne a kutatást nagyobb körben, a jelenleg alkalmazott kérdések felülvizsgálatával tovább folytatni. Különös tekintettel a pilot kutatás során felderített neuralgikus pontokra, annak érdekében, hogy az onkológiai ellátás során az egészségügyi szolgáltatást nyújtó szakemberek, a betegek és hozzátartozók egyaránt nagyobb biztonságban érezzék magukat.

Anyagi támogatás: A közlemény megírása anyagi támogatásban nem részesült.

Szerzôi munkamegosztás: F. H. J.: A kutatási módszertan kidolgozása, statisztikai elemzés, a kézirat első változatának elkészítése, javítás. Sz. A., Á. B., T. E.: Kérdőívszerkesztés, szakirodalom-kutatás, interjúk készítése, a tanulmány kiegészítése. A közlemény végleges változatát valamennyi szerző elolvasta és jóváhagyta.

Érdekeltségek: A szerzőknek nincsenek érdekeltségeik. 


\section{Irodalom}

[1] Weborvos: There are 378 medical malpractice cases against public hospitals. [378 kártérítési per folyik az államosított kórházakban.] http://weborvos.hu/egeszsegpolitika/378_karteritesi_ per_folyik/202496/[Hungarian]

[2] Public Foundation for Patient Rights, Rights of Beneficiaries and Children's Rights: Ten years patients' rights advocacy. [Betegjogi, Ellátottjogi és Gyermekjogi Közalapitvány: Tízéves a betegjogi képviselet.] 2010. http://www.jogvedok.hu/www/kozalapitva ny/10evesabetegjogikepviselet/lay/articles/show/107/10_ eves_a_betegjogi_kepviselet [Hungarian]

[3] National Center for Patients' Rights and Documentation: Report - 2015. [Országos Betegjogi, Ellátottjogi, Gyermekjogi és Dokumentációs Központ: Beszámoló - 2015.] www.obdk.hu/beszamolo-2015.html [Hungarian]

[4] Eurostat: Causes of death - standardised death rate, 2012 (per 100000 inhabitants). http://ec.europa.eu/eurostat/statisticsexplained/index.php/File:Causes_of_death_\%E2\%80\%94_ standardised_death_rate,_2012_\%28per_100_000_inhabitants\%29_YB15.png

[5] Structure in causes of death differentials in Hungary, 20002012. Hungarian Central Statistical Office, Budapest, May 2014. [A haláloki struktúra változása Magyarországon, 2000-2012. Központi Statisztikai Hivatal, Budapest, 2014. május.] https:// www.ksh.hu/docs/hun/xftp/idoszaki/pdf/halalokistruk.pdf [Hungarian]
[6] Horváth, J.: Oncology care - with question marks. [Onkológiai ellátás - kérdőjelekkel.] http://hirlevel.egov.hu/2015/01/25/ onkologiai-ellatas-kerdojelekkel/ [Hungarian]

[7] Cancer Index: Hungary Cancer Statistics 2012. http://www. cancerindex.org/Hungary

[8] Act CLIV of 1997 on Health. [1997. évi CLIV. törvény az egészségügyről - Nemzeti jogszabálytár.] http://njt.hu/cgi_ bin/njt_doc.cgi? docid=30903.290118 [Hungarian]

[9] Act LXXXIII of 1997 on the services of the compulsory health insurance system. [A kötelező egészségbiztosítás ellátásairól szóló 1997. évi LXXXIII. tv.] http://net.jogtar.hu/jr/gen/hjegy_doc.cgi?docid=99700083.TV [Hungarian]

[10] Kásler, M., Pikó, B., Poller, I., et al.: Remarks and recommendations on the organization and functioning of oncologic teams. Professional, ethical and financial issues of regulation. [Észrevételek és javaslatok az onkoteamek felépítésére és múködésére. A szabályozás szakmai, etikai és finanszírozási problémái.] Magy. Onkol., 2008, 52(3), 321-326. [Hungarian]

[11] Timár, J.: Role of contemporary pathological diagnostics in the personalized treatment of cancer. [A patológiai diagnosztika jelentősége a daganatos betegségek személyre szabott orvoslásában.] Magy. Onkol., 2013, 57(1), 26-32. [Hungarian]

(Feith Helga Judit dr., Budapest, Vas utca 17., 1088 e-mail: feith@se-etk.hu)

\section{TÉVESZMIÉK AZ ALTERNATIV GYÓGYÁSZATBAN?}

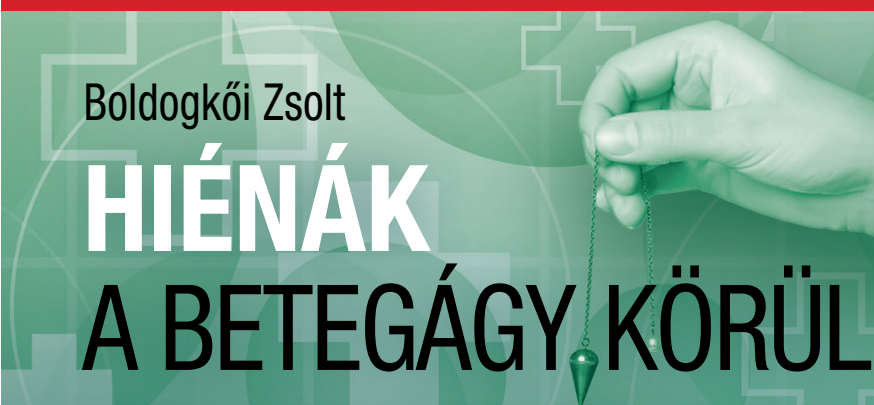

A szerző molekuláris biológusként elszántan küzd az áltudomány és a beteg ember kiszolgáltatott helyzetét kihasználó „kuruzslás” ellen. Könyvében a következő kérdéseket veti fel, állásfoglalása egyértelmü:

- Van-e tudományos alapja az íriszdiagnosztikának, homeopátiának, lúgositásnak, energiamezóknek?

- Miért csökken a tudományos gyógyitás presztízse, míg az alternatív gyógyitás népszerüsége egyre nő?

- Hogyan mérhető a terápia, a diéta hatása, miért hisznek a betegek csodaszerekben?

- Miért hajlandók sokan komoly összeget áldozni kétséges hatású terápiákra, szerekre, gyógyhatású készítményekre?

320 oldal, $3400 \mathrm{Ft} \bullet$ világraszóló tudás • www.akademiaikiado.hu
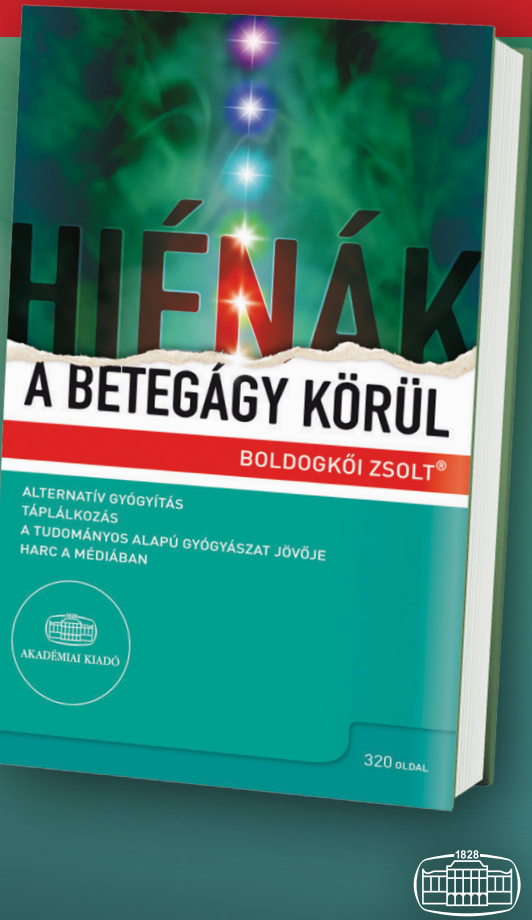

AKADÉMIAI KIADÓ 